\title{
Universiteit
}

Leiden

The Netherlands

\section{Political Modernity and Secularization: Thoughts from the Japanese Eighteenth and Nineteenth} Centuries

Paramore, K.N.

\section{Citation}

Paramore, K. N. (2012). Political Modernity and Secularization:

Thoughts from the Japanese Eighteenth and Nineteenth Centuries. Journal Of Religious History, 35(4), 1-12.

doi:10.1111/j.1467-9809.2011.01153.x/abstract

Version: $\quad$ Not Applicable (or Unknown)

License: $\quad$ Leiden University Non-exclusive license

Downloaded from: $\quad$ https://hdl.handle.net/1887/18469

Note: To cite this publication please use the final published version (if applicable). 


\title{
Political Modernity and Secularization: Thoughts from the Japanese Eighteenth and Nineteenth Centuries
}

\begin{abstract}
Although some politics and international relations discourses continue to maintain that there is a causal link between secularism and political modernity, religious studies, anthropology, and history research over the past decade has been rather merciless in debunking this idea as one of the tropes of Western imperialism. This article considers at how Japanese political thinkers of the eighteenth and nineteenth centuries engaged this trope, and how that engagement contributed to the particular relationship between religion and governance that emerged in the modern Japanese empire (1868-1945). The article argues that developments in the Confucian political thought of the Tokugawa shogunate (1603-1868), particularly in the works of Ogyū Sorai (1666-1728) and Aizawa Seishisai (1792-1863), contributed significantly to the capacity of Japanese thinkers and politicians to creatively engage the role of religion in Western imperialism during the nineteenth and twentieth centuries.
\end{abstract}

\section{Introduction}

The role of religion in the state structures and national ideology of modern Japan has been the object of considerable political and scholarly interest. ${ }^{1}$ In general, the use of religion by the modern Japanese state pre-1945 has been portrayed critically as a "deviation" from the "Western model" of a separation of church and state. This religious element in the pre-1947 Japanese nationstate model has been linked to negatively valued elements of Japanese history - like military expansionism and ultra-nationalism, for instance. ${ }^{2}$ Recent

1. H. Hardacre, Shintô and the State, 1868-1988 (Princeton, NJ: Princeton University Press, 1989); J. Ketelaar, Of Heretics and Martyrs in Meiji Japan: Buddhism and its Persecution (Princeton, NJ: Princeton University Press, 1990); J. Breen, ed., Yasukuni, the War Dead, and the Struggle for Japan's Past (New York: Columbia University Press, 2008).

2. Maruyama Masao 丸山真男, Gendai seiji no shisō to kōdō 現代政治の思想と行動 (Tokyo: Miraisha, 1964). Isomae Junichi 磯前順一, Kindai Nihon no shūkyō gensetsu to sono keifu: $s h \bar{u} k y \bar{o}, k o k k a$, shintō 近代日本の宗教言説とその系譜一宗教、国家、神道 (Tokyo: Iwanami shoten, 2003).

Kiri Paramore is University Lecturer in Pre-Modern Japanese History at Leiden University, the Netherlands. 
work on the West, however, and particularly on Western empire, has emphasized how religion was also employed in creating state, national, and imperial structures by Western empires and nations - and often with similarly problematic imperialist or expansionist aims. ${ }^{3}$

In this article I examine how the utilization of religious practices and paradigms in the construction of the ideological and legal frameworks of the modern Japanese nation-state and empire during the late nineteenth century, although doubtlessly seeking to copy perceived Western uses of religion in governance, was also profoundly influenced by ideas on the role of religion in governance which had emerged in Japanese political philosophy (Confucian discourse) during the eighteenth century. I pay particular attention to the influential Confucian political theorist Aizawa Seishisai (1782-1863). Through examining the influence of his early political writing, I look at how originally early eighteenth-century Confucian ideas on the place of religion in governance influenced the ideological constructs which contributed to the fall of the Tokugawa shogunate, and the construction of modern Japanese national ideology during the Meiji period.

\section{"Modern Japan" and the "Western Model"}

In 1888, the Japanese government produced the first modern constitution of a non-Western country. Itō Hirobumi (1841-1909), the Prime Minister, opened the constitutional convention which drafted this Imperial Constitution with the following words:

If we wish to establish a constitution now, first we must look for a central axis for our nation, and establish what we should say that central axis is. Without a central axis, then at times when governance is left to the disordered arguments of the masses, ordered governance will be lost, and thereby the nation lost. If we have any wish to make the nation a nation which will survive and rule the people, then we must consider this matter deeply, and plan so that the instrumentality of rule is not lost. In Europe, the seed of constitutional government has existed for around a thousand years. Not only the training of each person in this system, but the existence of religion, and the employment of religion as a central axis, deeply embedded in the minds of the people, has ultimately unified the minds of the people. In our country, however, religion does not possess this kind of power. Not one of our religions is capable of acting as the central axis of the nation. While at one point the power of Buddhism was very strong, capable of binding together people of all stations, these days that power has declined. Shinto is a learning based on the teachings of our imperial ancestors, but its power as a religion to direct the minds of the people is weak. In our country the only thing that can be used as a central axis is the imperial house. Therefore, in the drafting of the constitution, we must focus our minds on using this point, raising up imperial rule, and striving that it not be restrained. ${ }^{4}$

This quote concisely sums up the motivation for the creation of State Shinto. It offers one explanation for the construction of many of the political and

3. P. Van Der Veer, Imperial Encounters: Religion, Nation and Empire (Princeton: Princeton University Press, 2001).

4. Sūmitsuin 枢密院 (Privy Council), Sūmitsuin kaigi gijiroku 枢密院会議議事録, vol. 1 (Tokyo: Tokyo University Press, 1984), 156-57. 
ideological structures of modern Japan before 1945. This quote also provides a striking contemporary description of the nature of the modern Western nation from a diplomatically engaged Japanese observer on the ground. This description differs significantly from the way political modernity has often been imagined and presented in academic writing. ${ }^{5}$ For Itō, Western political modernity was certainly not about secularism - in fact quite the opposite.

In this sense, Itō's statement of 1888 fits nicely with current trends in academic writing on the role of religion in Western empire, which have pointed out the link between discourses on religion and modernity in places as diverse as India, Indonesia, and New Zealand. ${ }^{6}$ Western modernity was often foisted upon indigenous populations through religious mission, and conversely the Christian religion was often sold to the natives as a part of the modern Western world of science, technology, and even rationalism.

The Japanese case, however, is potentially even more interesting than India or Indonesia because of the comparative levels of agency and autonomy that Japanese politicians and intellectuals were able to exercise in their engagement with the West. ${ }^{7}$ Indigenous Japanese society and its political culture were not simply objects of Westernization and modernization. Conversely, they were primarily — through most of the twentieth century certainly — agents of modernization and Westernization, embracing and advocating Western political systems and technology and imposing it on others (China and Korea notably) in the same manner as (other) Western empires. On the other hand, in Japan there had developed, even before the beginning of a conscious programme of "modernization," an awareness of Western social, political, and scientific technology as both an object to absorb, but also to define national identity against. ${ }^{8}$ Examining the views of Itō and his predecessors, and the way those views emerged in political society, is therefore also of value in allowing us to better understand the fusions of indigenous and westernizing political traditions inherent in late nineteenth-century processes of modernization in general.

Most scholarly attention to the discussion of the role of religion in Japanese political society pre-1868, however, has tended to focus on the individual case of Japan, dealing with the sources predominantly in terms of national history narratives. ${ }^{9}$ There has been comparatively little attention to where this fits into

5. E. Gellner, Nations and Nationalism (London: Blackwell, 1983); S. Huntington, The Clash of Civilizations (New York: Simon and Schuster, 1996).

6. P. Van Der Veer, Nation and Religion: Perspectives on Europe and Asia (Princeton: Princeton University Press, 1999); B. D. Schildgen, G. Zhou, and S. L. Gilman, Other Renaissances: A New Approach to World Literature (New York: Palgrave MacMillan, 2007); J. Stenhouse \& A. J. Wood, eds., Christianity, Modernity and Culture: New Perspectives on New Zealand History (Melbourne: ATF Press, 2005).

7. C. Gluck, Japan's Modern Myths: Ideology in the Late Meiji Period (Princeton: Princeton University Press, 1985); A. Gordon, A Modern History of Japan: From Tokugawa Times to the Present (New York: Oxford University Press, 2003).

8. B. T. Wakabayashi, Anti-Foreignism and Western Learning in Early-Modern Japan (Cambridge, MA: Harvard University Press, 1986).

9. Maruyama, Gendai seiji no shisō to kōdō; Wakabayashi, Anti-Foreignism and Western Learning; Hardacre, Shintô and the State; Ketelaar, Of Heretics and Martyrs in Meiji Japan; 
global historical developments in both the political theory and historical reality of the relationship between church and state, or religion and state, in the development of global paradigms on governance and society. A notable exception is Ian Buruma, who has integrated this aspect of Japanese history into explanations of global historical trends. ${ }^{10}$ Here Buruma has referred to State Shinto as based on "a misunderstanding of the role of religion in the West." In this work, as in most of Buruma's others, his argument is a wonderfully clear articulation of the dominant paradigms of liberal ideology today. Following the determined historical teleology of that ideology, Buruma assumes that religion and state were of course successfully separated in the West during the so-called "enlightenment." His rather uncritical (or perhaps politically conscious) embrace of the ideological standpoint of "the enlightenment" determines his position that Itō's analysis could only ever be a "misunderstanding."

It would be very easy to oppose Buruma's position by stating simply that Itō's analysis was not a misunderstanding at all, but a good grasp on the reality of modern western imperial states: an insight to be learnt from. After all, if we look at the nexus between Western empire and religion at this time, be it the use of Catholicism in Vietnam, or the complex relations between religious, national, imperial, and colonial identities in India and Britain, or the phenomena of the Christian missions in China - all phenomena that Japanese leaders and thinkers were very familiar with throughout the nineteenth century - it is clear that interaction between religion and expansionist state activities existed. While for many Western intellectuals at the time, as for the likes of Buruma today, a range of later idealized political theories, pronouncements of Western self-identity, and ideology were used to reject the possibility of this analysis; the historical reality as observed on the ground by Japanese like Itō is fairly self-evident.

To simply say that the Japanese conception of the role of religion in modern nations was a sharp insight, however, in some ways brings us to the same end-point as stating that it was a complete misunderstanding. Both positions are based on looking at the situations in Japan and Europe pre-1850s as if they were totally unrelated and foreign phenomena. A more interesting inquiry is towards the commonalities in both Western and Japanese uses of religion in modern statecraft. In particular, to look at how these two interpreted each other when their political-judicial systems were (to an extent) standardized in the process of so-called "Westernization" or "modernization" in Japan in the late 1800 s. Looking at this historical background allows us to go beyond narratives of "reaction to the West" and rather look at the development of political ideas in Japan in parallel with the plurality of Western experiences, and the experiences of other societies during this period.

V. Koschmann, The Mito Ideology: Discourse, Reform and Insurrection in Late Tokugawa Japan, 1790-1864 (Berkeley and Los Angeles: The University of California Press, 1987).

10. I. Buruma and A. Margalit, Occidentalism: A Short History of Anti-Westernism (New York: Atlantic Books, 2003), 63. 


\section{Eighteenth- to Nineteenth-Century Japanese Confucian Political Philosophy}

The greatest influence on Itō by 1888 was undoubtedly his own experience of Western methods of statecraft. Sent by the rebel Chōshū domain to study in England in 1863, he had since his return to Japan been at the centre of negotiations with Western powers and the construction of systems of Meiji governance, all based in Western political and legal frameworks. The drafting of the Imperial Constitution in 1888 represented an end-point to this first phase in the political, legal, economic, military, and commercial Westernization of Japan. $^{11}$

Itō was also influenced by a political tradition which had developed a role for what we could call religion in statecraft through a primarily non-Western tradition of Confucian political philosophy. One particularly powerful treatise of Confucian political philosophy which deeply influenced Itō and most other samurai who played central roles in the Meiji revolution was the 1825 work New Theses (Shinron 新論) written by the Mito domain samurai and Confucian intellectual Aizawa Seishisai. New Theses, in a tradition of Confucian political writing seen throughout the previous 200 years, called for reform and improvement of shogunal systems of government to bring them into line with the writer's vision of a Confucian ideal of governance. Of course, each of the Confucian political writers through the 250 years of the Tokugawa Shogunate had their own view of what this Confucian ideal of governance was. Seishisai's politicial philosophy standpoint was influenced primarily by the earlier Tokugawa Confucian thinker, Ogyū Sorai (1666-1728) and nativist reactions to Sorai from the late eighteenth century. ${ }^{12}$ Seishisai's views, however, were explicated primarily in terms of a reaction to the threat of Western imperialism, sometimes even referring to the efficacy of elements of Western political practice in contrast to (from Seishisai's perspective) problematic elements of contemporary Chinese and Japanese governance.

In Shinron and later writing, Seishisai identified links between governance and religious practice as the key to maintaining the integrity of the Japanese state. ${ }^{13}$ Seishisai, following a number of earlier Tokugawa scholars, regarded the success of Western imperial expansion as being primarily due to the incredible levels of political and social integration provided by the politicoreligious systems of Western states, rather than technology, capitalism, or gunpowder. ${ }^{14}$ The key to these systems, and the chief difference with the declining Chinese and Japanese, was the West's use of Christianity. Seishisai

11. Satō Yoshimaru 佐藤能丸, Meiji nashonarizumu no kenkyū 明治ナショナリズムの研究 (Tokyo: Fuyōshobō, 1998), 10.

12. On the influence of Sorai on Seishisai, see Bitō Masahide 尾藤正英 "Mitogaku no tokushitsu”, in Mitogaku 水戸学, Nihon shisō taikei 日本思想大系, vol. 53, edited by Bitō Masahide (Tokyo: Iwanami shoten, 1973), 564-65. As Peter Flueckiger has noted, National Learning writing was also predominantly carried on through Confucian conceptual forms and frameworks; see "Reflections on the Meaning of Our Country: Kamo no Mabuchi's Kokuikō," Monumenta Nipponica 63, no. 2 (2008): 212.

13. Aizawa Seishisai 会沢正志斎, “Shinron 新論,” in Mitogaku 水戸学, Nihon shisō taikei 日本思想大系, vol. 53, edited by Bitō Masahide (Tokyo: Iwanami shoten, 1973), 70-74.

14. Aizawa Seishisai, "Shinron," 94-96. 
saw in Christianity Western states' central deployment of the "prerogative" or "method" (ken) of what in the Confucian political philosophical tradition was called "rites and music" (reigaku 禮樂). ${ }^{15}$ Twentieth-century scholars have described this Tokugawa conception of the political utilization of rites and music as "religion," the deployment of religious practice in statecraft. ${ }^{16}$

The major intellectual influence on Aizawa Seishisai's conception of the central importance of rites and music, and indeed the major figure in the history of Tokugawa Confucianism, was Ogyū Sorai (1666-1728). One of Sorai's major philosophical positions was to equate the Confucian "Way" (the means of achieving social harmony in line with nature) with the rites and music of the Ancient Sage Kings of semi-mystical Chinese antiquity. This was the idea of rites and music which Aizawa Seishisai employed. ${ }^{17}$

Ogyū Sorai is famous in the history of Confucianism for having established the most complete break with the metaphysically inclined interpretation of Confucianism established by Zhu Xi (1130-1200) during the Song dynasty in China. Developed under the influence of and in reaction to Chan Buddhism, this form of Zhu Xi Confucianism, usually labelled either Song Confucianism or Neo-Confucianism, had been generally accepted as the Confucian orthodoxy for several centuries. It established an integrated metaphysical system which sought to explain the origins and function of the world and human society in terms of an interaction between principle and substance. ${ }^{18}$ The political philosophy ramifications of this Confucianism were based on its emphasis on the moral development of individuals as a means to establishing a harmonious, just, and virtuous human society. This is the "Confucianism" referred to in classic Western philosophical and political literature, and indeed in much modern Chinese writing, as the conservative morals-based form of thinking which held back enlightenment and development in East Asia (Hegel, Marx). ${ }^{19}$

The development and adoption of this system as ideology in China and Korea during the first half of the second millennium CE occurred in tandem with the development of bureaucratically rather than feudally ruled large and complex states in these countries. The much later rise of Zhu-Xi-ist Confucianism in Japan as a politically favoured mode of thought and political discourse from the 1600 s onwards also coincided with the rise of a more complex, integrated, and (comparatively in terms of the history of Japan) more

15. Aizawa Seishisai 会沢正志斎, Kikōben 峘好弁 (Gyokugenshodō, 1857), 11b, 12a.

16. Wakabayashi, Anti-Foreignism and Western Learning, 132-33.

17. On Ogyū Sorai, see O. Ansart, L'empire du rite: La pensée politique d'Ogyū Sorai, Japan 1666-1728 (Paris: Droz, 1998); and T. Najita, Tokugawa Political Writings (Cambridge: Cambridge University Press, 1998).

18. On the metaphysics of Zhu Xi Confucianism see Feng Youlan, A Short History of Chinese Philosophy (New York: Free Press, 1966); Yao Xinzhong, An Introduction to Confucianism (Cambridge: Cambridge University Press, 2000).

19. M. Weber, The Religion of China (New York: The Free Press, 1951), 164-67. G. W. F. Hegel, Lectures on the History of Philosophy: Greek Philosophy to Plato, trans. E. S. Haldane (Lincoln: University of Nebraska Press, 1985), 121-25. I have briefly discussed the problems inherent in this outlook and the danger of its resurrection through recent post-modernist scholarship in K. Paramore, "Religion and Global Empire," IIAS Newsletter, no. 54 (2010): 17-18. 
centralized Japanese state under the Tokugawa Shogunate. The power structures of the Tokugawa shogunate, however, in contrast to those of China and Korea, were in essence structurally feudal - the central government (shogunate) holding sway over nominally self-governing domains through the establishment of sovereign-vassal relations between the Shogun and the domainal lords. ${ }^{20}$ Furthermore, the internal power structures and political appointments both within the shogunate and within each of the over-200 domains were also based on hereditary vassal relations - almost all political positions thereby being assigned hereditarily. ${ }^{21}$

Sorai, in his major works written in Edo (Tokyo) in the 1710s, completely rejected Zhu Xi Confucianism as a Song fabrication. For Sorai, Confucian truth was located essentially not in moral prescriptions of scholar-writers of the second- to twelfth-common-era centuries, but earlier, in the historical truth of the rule of the "Ancient Sage Kings" of Chinese antiquity — pre-700 BC. This period - the Zhou dynasty and before, Sorai Confucianism's golden age was a time when historically, as Sorai correctly pointed out, political structures in Chinese society were feudal. According to Sorai, the guides to social relations spoken of in Confucian texts, therefore, should be interpreted primarily as applying to relations between vassal and sovereign, lord and retainer, and, to a lesser extent, lords and subjects.

According to Sorai, the Confucian classics themselves were written for no other purpose than to instruct the ruling class (Sorai's clear interpretation of the "Confucian gentleman" (Ch: junzi, Jp: kunshi, 君子) in the classics, and in the Japanese contemporary context thereby denoting samurai 士) in how to rule over society. For Sorai, the way to hold sway over society was not through so-called Confucian self-cultivation, which Sorai labelled as "selfish" and "Buddhist," but through the rites and music established by the Ancient Sage Kings in Chinese antiquity and revealed in the ancient texts. Sorai's rites and music concept, although proposed as the underpinnings of a political system, emphasized a practice that was clearly religious, even transcending the temporal world.

Pervading heaven and earth, the substance of the rites reaches minute, subtle areas, giving everything its standard, and providing systematic order to irregularities. There is no aspect of the rites that the way does not penetrate. Princes study them, while the common people follow them. The method of studying the rites begins with practice to the point of proficiency and culminates in a silent comprehension ....

By following the rites, people are transformed. Once transformed, they follow the rules of the Lord on high (tei, $d i$ 帝) unconsciously and unknowingly. How could there possibly be anything that is not good if the rites are thoroughly followed? ${ }^{22}$

20. On the feudal nature of the Tokugawa state, and on the use of the term "feudal" to describe it, see D. Howell, “Territoriality and Collective Identity in Tokugawa Japan," Daedalus 127, no. 3 (1998): 116-17.

21. On the interaction between hereditary and bureaucratic forms of appointment during the early- to mid-Tokugawa period, see Fujii Jōji, Edo jidai no kanryōsei (Tokyo: Aoki Shoten, 1999).

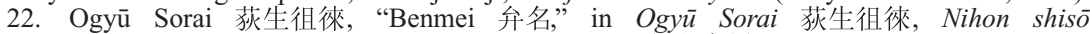
taikei 日本思想大系, vol. 36, edited by Maruyama Masao 丸山真男 et al. (Tokyo: Iwanami shoten, 
Rites and Music were of course practice, but practice tied intimately to doctrine through the Book of Rites and other classics, and tied intimately to faith and piety because rites and music were the ultimate expression of the Emperor's reverence for Heaven. They were the bases of people's reverence for Heaven, through their performance of rites and music to their families, lords, rulers, and through the hierarchical system of the five relations. Sorai saw this system as having been established in history by the Sage King Yao under the influence of Heaven.

"Reverently follow august Heaven." This is how Yao modelled himself on Heaven. The book of Yao also says [of Yao], "reverent, enlightened, cultured, and thoughtful." Here what is of Heaven is called culture, while that which is of the earth I called principle. Culture is the way of Heaven, meaning rites and music. ${ }^{23}$

What had previously been referred to in Neo-Confucianism as absolute moral values such as benevolence and righteousness were interpreted by Sorai instead as manifestations of social relations demonstrated through the practice of rites and music. The understanding of these as abstracted values was pointless, rather they were to be practised, the basic understanding of them being a prerogative of only the rulers and achievable only in relation to the utilitarian considerations of given social and periodic contexts.

The teachings of the early kings are precisely what promote the highest good. While their teachings of rites and music should be silently comprehended, some people can fathom them, but others cannot. For that reason, Confucius, when discussing "ritual principles" (righteousness gi/yi 義), would only explain occasionally to his disciples one part of it. "Ritual principles" refer to the principles by which the early kings founded the rites. Everything recorded in Elder Tai's Rites and the Book of Rites conveys these. Some people, however, can comprehend this, while others cannot. ${ }^{24}$

Sorai's original take on Confucianism became popular in his own lifetime, and continued to hold sway as one of the dominant trends in Confucian political thought in Japan, even into the modern period. Figures like Nishi Amane (1829-1897) — a contemporary of Itō Hirobumi's, one of the earliest Japanese experts on Western philosophy, and (after studies in Leiden) the initiator of many of the modern legal institutions of Meiji Japan — continued to show the influence of Sorai throughout his life. ${ }^{25}$

Sorai's work was also possibly just as important as the provocateur of the growth of Japanese nativism or Kokugaku 国学, one of the major intellectual currents linked to the growth of emperor-centric nationalism and the Meiji Restoration of 1868. Key early figures in Japanese nativism, like Motoori Norinaga (1730-1801), deliberately replaced Sorai's idealized ancient Chinese past with a set of imagined traditions and customs of an "ancient" Japanese

1973 ) (NST 36) 70; J. A. Tucker, ed. and trans., Ogyū Sorai's Philosophical Masterworks: Then Bendō and Benmei (Honolulu: University of Hawaii Press, 2006), 205.

23. Ogyū Sorai 荻生徂徠, “Rongochō 論語徵,” in Ogyū Sorai Zenshū 荻生徂徠全集, vol. 3, edited by Imanaka Kanshi 今中宽司 (Tokyo: Misuzu shobo, 1977), 352. The quotes are from the opening section of the Book of Documents.

24. Ogyū Sorai, Benmei, 71 .

25. Nishi Amane, Nishi Amane Zenshū, vol. 1 (Tokyo: Munetaka shobo, 1965), 3-16. 
past. Based on a sanctification of Japanese classical literature and invented custom, many of Norinaga's ideas were clearly searching for indigenous rites and music. The Kokugaku of Norinaga, although originally conceived in direct opposition to Sorai's ideas, came to be in part integrated into some forms of Japanese Confucian political philosophy, notably that of Aizawa Seishisai. ${ }^{26}$

\section{Japanese Confucianism's Lens on Christianity as Statecraft}

Seishisai partly engaged and partly courted the popularity of nativist ideas, not only through his clear Japanese nationalism, but also through his disparagement of China, and his positioning of the Japanese imperial line as objects of religious worship. He to some extent conflated Sorai Confucianism with nativism by advocating a system which at its heart inserted Japanese emperors in the place of the roles Sorai saw the Chinese Ancient Sage Kings playing in history.

In antiquity, religious ritual and governance were one, administration was ultimately identical with edification, and the people looked to their leaders for the fulfillment of the desires . . . there was a ritual for every meaning His Majesty sought to convey, and through these rituals the people became aware that the Emperor's [wishes/prayers] were intended to benefit them. They rejoiced in this realization and their loyal and filial devotion were made pure and directed to but one object. ${ }^{27}$

Seishisai's view of the West's deployment of Christianity for social control was coloured totally by Sorai's conception of rites and music, as delivered both through Sorai's own philosophy, and the bastardized nativist versions of it presented later by the Japanese nativist movement. Seishisai analysed the Western imperialist deployment of religion through the Sorai constructed idea of rites and music. Of course, as Seishisai himself explained, what he saw the Westerners using were not the "real" "natural" rites and music of the ancient Sage Kings, but another kind of rites and music which functioned similarly.

In later times, the barbarians [Westerners] established classic texts of their own that sound very much like the genuine ones prescribed [by the sages] in antiquity. Armed with this Way of wickedness, they eat into the people's hearts and minds. ${ }^{28}$

Seishisai's conception of the link between Christianity's political role in the West, and his own idealized system of Confucian statecraft, is most readily discerned from a text that was particularly popular at the time of its writing but has been understudied by modern scholars - Kikōben. In this text Seishisai made clear his position that Christianity had stolen the "method" (Jp. ken Ch. chuan) of the (Confucian) sages and had copied their force. ${ }^{29}$ In this sense, their system, and that of the sages were comparable. Both had culture (Jp. bun, Ch. wen), which Seishisai equated with the Way; both had rites and music; both worshipped Gods and Heaven. ${ }^{30}$ But for Seishisai, one was of course better

26. P. Nosco, Remembering Paradise: Nativism and Nostalgia in Eighteenth Century Japan (Cambridge, MA: Harvard University Press, 1990), 244-45.

27. Aizawa Seishisai, Shinron, 152. English translation can be found in Wakabayashi, AntiForeignism and Western Learning, 126.

28. Aizawa Seishisai, Shinron, 143.

29. Aizawa Seishisai, Kikōben, 15.

30. Aizawa Seishisai, Kikōben, 8, 12. 
than the other. The Way of the sages was "natural" and "true" for him, just as for Hugo de Groot the "Christelyke" religion was more perfect and "true" (ware) than others. But they were comparable systems. ${ }^{31}$

Seishisai clearly compared his conception of the "Way of the Sages" to Christianity, Islam, and other religious systems. ${ }^{32}$ In Shinron and in his contemporaneously written anti-Christian apologetic, Kikōben 豈好弁, Seishisai spoke in parallel of Christianity with other religions using a variety of terminology. In Kikōben he referred comparatively to a number of different foreign religions, kyōho 教法, which he identified in the opening of the treatise as Islamic (kaikaihō 回回法), Indian (Buddhism) (tenjikuhō 天竺法), and Western (Christian) (seiyōhō 西洋法). ${ }^{33}$

Whether following the Way of the Sages or the Way of the Barbarian Gods, China/Japan and the West were described as worshipping Heaven or the Lord of Heaven and employing rites and music. The difference, however, was that in the Central Kingdom (China/Japan), Heaven was originally (by the sages) worshipped correctly through fathers and sovereigns, while in the West the rites were used to worship a "barbarian god" (Christ) who was set up to displace the natural social relations which underlay order. ${ }^{34}$ The Way of the Sages was contrasted against The Way of Barbarian Gods. They were compared to the extent that Seishisai inferred that the Christians used the same utility/ instrumentality of the rites and music as the ancient sages, and even better than Chinese of "latter ages" (meaning post-Tang). ${ }^{35}$

Normal human sentiment is to stand in awe of Heaven's authority. So the Sages revered Heaven. Serving Heaven was like serving their parents. Through their ancestors, they offered to Heaven. Serving their ancestors was also like serving Heaven. There were the appropriate rites and the appropriate music ... In this way the masses came to have a mind to stand in awe of Heaven's authority, and thereby revere the sovereign. Heaven and sovereign were one. The masses were nurtured. This is the sages' great prerogative and method of governing the world and ruling the masses. The barbarians and their lackeys set up a foreign god, and using this they corrupt the stupid masses. Thereby they use the masses natural inclination to respect Heaven [their natural religious inclination] to get them to respect their rulers and betters. This is a contingent and created story. It is not natural. It is nothing more than the stealing of the sages' prerogative and methods. The sages also relied on the energy of this prerogative and method, and they used it to lead the masses. But the Way of the Sages was nature as created by Heaven. The multifarious things originated in Heaven, the people originated from their ancestors, so they served the Lord on High, and they sacrificed before him. ${ }^{36}$

\section{Religious Practice and Alleged Secularization}

This later development of Confucian political philosophy on the role of the institutionalization of religious practice as part of nation-state construction and

31. H. de Groot, Bewys van de ware godsdienst in ses boeken gestalt (Amsterdam:

R. Stemvers, 1844), 57.

32. Aizawa Seishisai, Kikōben, 1a.

33. Aizawa Seishisai, Kikōben, 1a

34. Aizawa Seishisai, Kikōben, 9a,b.

35. Aizawa Seishisai, Kikōben, $12 \mathrm{~b}$.

36. Aizawa Seishisai, Kikōben, 12a. 
national expansion clearly originated in Confucian political philosophy paradigms, but can also be seen to have interacted directly with observation of the employment of religion in Western imperial expansion. This was the writing that formed an important ideological underpinning of the Meiji revolution and the reform of government - especially in regard to the role of religion which followed.

The key developmental background to this writing, however, was clearly the move in the eighteenth century away from a Zhu Xi Confucian emphasis on morals to the Sorai Confucian inspired emphasis on rites and music: a move from justification of order based on shared moral norms, to one based on shared religiously inclined social practice.

If we see the major intellectual change represented by Sorai and those who came after him as a focus on addressing social problems (order, stability, state-maintenance) by unifying governed society through practice rather than morals norms, then surely the way we look at the phenomenon that has been labelled "secularization" is also challenged. It seems that the shift that occurred towards more so-called "modern" views of politics has more to do with an emphasis on religious practice rather than religious morals. The key point of change here seems not to be related to degrees of "religiousness" or "secularization," but rather related to what elements of religious life are used to justify governance. Or to put it differently, what element of religion is integrated into the political realm.

Much earlier discussion on the role of secularization in Japanese political modernization can be seen as alluding to this problem The preeminent twentieth-century expert on the history of early-modern and modern Japanese political thought, Maruyama Masao (1914-1996), explained the banning of Christianity in the early 1600 s in terms of the long-term political history of Japan:

We should not focus on each individual ruler's policy of prohibiting Christianity as a "foreign religion," but rather look at the prohibition of Christianity from within the context of the overall process of domestic political change which occurred in Japan from the end of the Muromachi period [1573] through into the Tokugawa period [1603-1868]. This process gave birth to early-modern systems of control, bringing religious power in general into confrontation with secular authority, religious influence in the end becoming completely subordinated to the latter in one of history's great moments of change. ${ }^{37}$

Maruyama here suggested that the large scale suppression of the power of organized Buddhist religious and lay people by war lord leaders in the second half of the sixteenth century, and the later suppression of Christianity in the early seventeenth century, were both part of a process of "secularization" establishing "early-modern systems of control" in Japan. He described this process as "complete subordination" of religion to political authority.

Maruyama saw this secularization process as having been a pillar for creating the state-structures that he condemned as authoritarian but which he also -

37. Maruyama Masao 丸山真男, Kōgiroku 講義録, vol. 6 (Tokyo: Tōkyō daigaku shuppankai, 2000), 119-20. 
intriguingly for someone who identified himself as a modern liberal — associated with modernization. Maruyama's position on the role of religion in modern Japanese politics in the twentieth century is directly reflected in the writing of Buruma. Maruyama also held up the reality of Japanese history to the twentieth century liberal ideal of the separation of church and state - and found Japan wanting. In other words, he saw Japan (in the twentieth century) as not "secularized" enough.

Yet it is also Maruyama's analysis which clarified the central role secularization played in the development of the forms of authoritarianism that, in his view, linked the histories of the early-modern and modern Japanese states. As early-modern Japanese thinkers like Aizawa Seishisai guessed, and modern Japanese governors like Itō Hirobumi proved, the models of modern Western imperialism were particularly adept at the cultivation of an authoritarian state. The secularization Maruyama spoke of in regard to the early-modern state was one that emerged during, yet seemingly independently of, the first period of contact with the West in the sixteenth century. ${ }^{38}$ The modern models for the relationship between state and religion adapted by the Meiji state in the nineteenth century, however, were clearly based on observation of the European powers. "Secularism" - meaning subordination of religion to the political imperatives of the imperialistic state - was present in both, a link between the early-modern and modern Japanese orders, the antecedents of which lay as much in the indigenous political constructions of the Tokugawa state as in the reception (and eventual replication) of the ideologies of Western imperialism.

38. K. Paramore, Ideology and Christianity in Japan (New York: Routledge, 2009). 